\title{
Species distribution models do not account for abundance: the case of arthropods on Terceira Island
}

\author{
Alberto Jiménez-Valverde ${ }^{1,2, *}$, Francisco Diniz ${ }^{1}$, Eduardo B. de Azevedo ${ }^{3}$ \& \\ Paulo A. V. Borges ${ }^{1}$
}

1) Azorean Biodiversity Group (CITA-A), Universidade dos Açores, Dep. de Ciências Agrárias, Terra-Chã, 9700-851 Angra do Heroísmo, Terceira, Açores, Portugal ( ${ }^{*}$ corresponding author's e-mail:ajvalv@ku.edu)

2) Present address: Natural History Museum and Biodiversity Research Center, The University of Kansas, Lawrence, Kansas 66045, USA

3) CMMG (Centro de Estudos do Clima, Meteorologia e Mudanças Globais), Universidade dos Açores, Dep. de Ciências Agrárias, Terra-Chã, 9700-851 Angra do Heroísmo, Terceira, Açores, Portugal

Received 27 Feb. 2009, revised version received 10 May 2009, accepted 22 May 2009

Jiménez-Valverde, A., Diniz, F., de Azeved, E. B. \& Borges, P. A. V. 2009: Species distribution models do not account for abundance: the case of arthropods on Terceira Island. - Ann. Zool. Fennici 46: 451-464.

The objective of this study is to investigate whether presence/absence models can be used as surrogates of arthropod abundance, and eventually under which circumstances such surrogacy is guaranteed. Presence/absence data for 48 arthropod species from Terceira Island were modelled using artificial neural networks. Probabilities of occurrence were correlated with abundance data from a standardized arthropod survey programme. Although a tendency was found for vagile species to show relationships, only nine species showed significant positive correlations between probability of presence and abundance. Five of these were exotic spider species with high abundances and wide distributions in several human-modified habitats. The patchy distribution of pristine habitats, the capacity to reach them and the probable low dependence on limiting resources, other than food, enhance the relationship. A lack of significant correlations for the majority of the species may be due to historical events, inappropriate scale, demographic controls of density, or the incapacity of presence/absence models to account for environmental suitability. The difficulty to identify a priori the species for which the relationship will hold advises against the use of species distribution models as surrogates of arthropod abundance.

\section{Introduction}

Species occurrence and abundances are key variables in modern ecological and conservation sciences (see Gaston \& Blackburn 2000 and references therein). Moreover, understanding spatial and temporal patterns of distribution and abundance is critical to assess the threat status of species (Regan et al. 2000, Conrad et al. 2006). The abundance of a species is ultimately a function of its birth and death rates, which depend on its fitness in different environments (Boyce 
\& McDonald 1999, Pearce \& Ferrier 2001, Tyre et al. 2001, but see Van Horne 1983). Besides, abundance is closely related to persistence, a property of the population that is desirable to maximize in reserve selection schemes (Mangel \& Tier 1994, Araújo \& Williams 2000). It follows that predicting population densities across its distributional range is of great value for conservation and management purposes, in order to assess the impact of environmental changes on organisms (Boyce \& McDonald 1999, Joseph et al. 2006, Smith et al. 2006).

However, the logistical difficulties of obtaining abundance data in many locations are particularly relevant for arthropods. Many projects are currently compiling information on species distributions (e.g. GBIF at www.gbif.org, ATLANTIS www.azoresbioportal.angra.uac.pt; Borges 2005, Hortal et al. 2007), but spatial data from these databases have no associated abundance data, which makes them at least incomplete. In fact, presence data are much easier to survey, and are available in numerous biological databases (Soberón \& Peterson 2004, Hortal et al. 2007). This is one of the reasons why predictive distribution models have developed rapidly in the last decade (Scott et al. 2002). By quantifying species-environment relationships and prediction of species' geographic distributions from confirmed occurrences, they assume a direct link between the probability of presence and environmental suitability (Pearce \& Ferrier 2001, Peterson 2006). Such models can be used to develop management decisions and conservation strategies (Schadt et al. 2002, Barbosa et al. 2003, Hirzel et al. 2004, Russell et al. 2004), among other practical and theoretical applications (see Peterson 2006 for a review). Their usefulness would be greatly strengthened if a relationship between local probability of occurrence and abundance were to exist. Moreover, several authors have recently pointed out that relating probability of occurrence to abundance could be a powerful way of validating presence/absence models (Albert \& Thuiller 2008, Lobo et al. 2008).

A positive relationship between the probability of occurrence and local abundance is expected when there is a strong relation between population densities and environmental variables (Pearce \& Ferrier 2001). Moreover, the relation- ship will be enhanced if resources are limiting and patchy and if the densities of the populations are at their upper limit, as at low densities, other factors apart from environment may be determining the size of the populations (Mitchell 2005, Nielsen et al. 2005). However, factors other than environment will make species reach high densities in places with low probability of occupancy (Van Horne 1983, Tyre et al. 2001, Nielsen et al. 2005). For example, biotic interactions such as aggregation, intraspecific competition or predator pressure can force individuals to concentrate in unsuitable sink marginal habitats. Thus, the relationship between probability of occurrence and local abundance is a complex phenomenon that depends on many different factors acting in isolation or in synergy. However, little empirical work has been undertaken to study the capacity of occurrence models to account for local abundance. To our knowledge, only two studies specifically address the question: (i) Pearce and Ferrier (2001) tested the capacity of logistic presence/absence models to predict population densities of several species of vertebrates and vascular plants, but found little correlation between the probability of presence and abundance among occupied sites; (ii) likewise, Nielsen et al. (2005), studying a fern and a moose, obtained disappointing results regarding probability of presence as a surrogate of abundance, attributing their negative results to unmeasured factors, such as site history, that ultimately determine abundance. Recently, in a study not focused on this question, Real et al. (2009) found significant relationships between environmental favourability and abundance in two vertebrates in Spain, the Iberian lynx and its prey, the European rabbit. All these results are inconclusive and no inference about the circumstances, if any, under which probability of occurrence acts as a surrogate for local abundance can be deduced.

In this study, we use information derived from a replicated, intensive arthropod sampling scheme on Terceira Island (Azores) in several habitats (see Borges et al. 2005a, 2006). We evaluated the degree to which environmental suitability assessed with presence/absence models account for abundance estimates. By comparing numerous arthropod species with diverse biological characteristics, we tried to assess the con- 
ditions under which the relationship holds. We hypothesize that the wider the distributions and the higher the global abundance, the stronger the relation will be. Thus, we expect the relationship to be enhanced in the case of vagile species able to colonize all suitable habitats. As occurrence models can have two different interpretations (potential versus actual distributions), depending on the kind of distribution data and predictors used (Soberón \& Peterson 2005, Jiménez-Valverde et al. 2008), we developed two types of models to assess if there are any differences in their relation with abundance.

\section{Data and methods}

\section{Biological data}

For this study we used a large dataset of epigean arthropod species sampled with pitfall traps in a standardised, large-scale biodiversity study in the Azores (BALA Project - Biodiversity of Arthropods from the Laurisilva of the Azores; for more details see Borges et al. 2005a, 2006, Gaston et al. 2006, Hortal et al. 2006). Pitfall traps measure activity densities rather than true abundances of species (Luff 1975). Thus, for the same species, they can be used to compare between-sites relative number of individuals and assume that they are a direct estimate of between-sites relative true abundances (Curtis 1980, Downie et al. 2000). As in Borges et al. (2006), only data from the most intensively surveyed island, Terceira, were included in the analysis. Fieldwork was conducted between 1999 and 2005, during the summer months following a gradient of anthropogenic modification from pristine, high-elevation native forest to low-elevation anthropogenic intensive pasture (Borges et al. 2008, Cardoso et al. 2009). At each location $(N=81)$, one $150 \times 5 \mathrm{~m}$ transect was used to record species occurrences (presence or absence data) and estimate their local abundances as the number of recorded individuals, assuming that, as pointed out before, these intraspecific between-sites relative numbers are direct indicators of the intraspecific between-sites relative size of local densities. A total of 30 pitfall traps were used in each transect (see also Borges et al. 2005a, 2006). Data were referred to $500 \times 500 \mathrm{~m}$ UTM grids. In cases where two or more transects fell in the same grid (8 cases, 67 final UTM grids with abundance data), the mean abundance for each species was used. BALA transects provided abundance data (Table 1) as well as presence/ absence information. In addition, we collated presences of each species in $500 \times 500 \mathrm{~m}$ grids from the GIS-based ATLANTIS database (see Borges 2005 and www.azoresbioportal.angra. uac.pt) to increase their number for occurrence models.

We chose a $500 \times 500 \mathrm{~m}$ spatial resolution as we consider it to represent an appropriate balance between the incidences of the fauna on BALA transects (both presence/absence as well as relative abundances for each species among cells) and minimization of the effects of other variables (competition, stochasticity, etc.) on population abundances and species presences. A lower resolution (larger cell size) for such a small territory as Terceira Island would suppose the loss of a large amount of variability in the predictors and a drastic reduction in sample size. A $500 \times 500 \mathrm{~m}$ spatial resolution has been previously used in other works with arthropods in the Azores (e.g., Hortal et al. 2005).

We discarded species from the BALA (Borges et al. 2005a, 2006) and ATLANTIS (Borges 2005, www.azoresbioportal.angra.uac.pt) databases if they were: (i) recorded in $<10$ localities with non-zero abundances; (ii) recorded in $<10$ localities with abundances $=0$ (real absences in real distribution models, see below); or (iii) with $<10$ probable absences (absences in potential distribution models, see below). From an initial pool of 207 species, 48 were selected for further analysis (see Appendix).

\section{Predictor variables}

Landscape heterogeneity is a key factor in determining species distribution, abundance and diversity. We used volcanic, topographic, climatic and land-use variables to model the real and potential distribution of species (see below). As in our GIS database the original spatial resolution of raster maps was at $100 \times 100 \mathrm{~m}$, all maps in the database were resampled to a $500 \times 500 \mathrm{~m}$ resolution. 
Table 1. Characteristics of the training data for the potential distribution models (sample size and prevalence), accuracy statistics (sensitivity, specificity and AUC) and results of the correlation analysis between probability of occurrence and abundance ( $r_{\mathrm{s}}$ and $p$ values).

\begin{tabular}{|c|c|c|c|c|c|c|c|}
\hline Species & Sample size & Prevalence & Sensitivity & Specificity & AUC & $r_{\mathrm{s}}$ & $p$ \\
\hline \multicolumn{8}{|l|}{ Araneae } \\
\hline Agyneta decora & 380 & 0.10 & 1.00 & 0.99 & 1.00 & -0.45 & 0.1058 \\
\hline Dysdera crocata & 195 & 0.63 & 0.98 & 0.97 & 1.00 & 0.37 & 0.0141 \\
\hline Eperigone bryantae & 138 & 0.49 & 0.97 & 0.97 & 1.00 & 0.42 & 0.1083 \\
\hline Eperigone fradeorum & 82 & 0.40 & 0.97 & 0.98 & 1.00 & 0.60 & 0.0515 \\
\hline Erigone atra & 386 & 0.10 & 0.97 & 0.97 & 0.99 & -0.01 & 0.9827 \\
\hline Erigone autumnalis & 135 & 0.43 & 0.97 & 0.96 & 1.00 & 0.45 & 0.0162 \\
\hline Erigone dentipalpis & 143 & 0.41 & 0.98 & 0.99 & 1.00 & 0.58 & 0.0020 \\
\hline Ero furcata & 402 & 0.11 & 0.98 & 0.98 & 0.99 & 0.36 & 0.1284 \\
\hline Lepthyphantes acoreensis & 450 & 0.10 & 0.98 & 0.98 & 1.00 & - & - \\
\hline Meioneta fuscipalpis & 260 & 0.10 & 0.96 & 0.97 & 0.99 & -0.31 & 0.3217 \\
\hline Oedothorax fuscus & 105 & 0.70 & 0.99 & 1.00 & 1.00 & 0.41 & 0.0258 \\
\hline Ostearius melanopygius & 153 & 0.40 & 0.98 & 0.98 & 1.00 & 0.27 & 0.3215 \\
\hline Pachygnatha degeeri & 244 & 0.13 & 0.97 & 0.97 & 1.00 & 0.31 & 0.2613 \\
\hline Palliduphantes schmitzi & 410 & 0.10 & 0.98 & 0.98 & 0.99 & - & - \\
\hline Pardosa acoreensis & 456 & 0.27 & 0.98 & 0.99 & 1.00 & 0.26 & 0.0682 \\
\hline Porrhomma borgesi & 230 & 0.10 & 1.00 & 0.99 & 0.99 & -0.37 & 0.2122 \\
\hline Prinerigone vagans & 91 & 0.60 & 0.98 & 0.97 & 1.00 & 0.46 & 0.0455 \\
\hline $\begin{array}{l}\text { Rugathodes acoreensis } \\
\text { Blattaria }\end{array}$ & 380 & 0.10 & 1.00 & 1.00 & 1.00 & 0.08 & 0.7509 \\
\hline $\begin{array}{l}\text { Zetha vestita } \\
\text { Chilopoda }\end{array}$ & 102 & 0.44 & 0.98 & 0.98 & 0.98 & -0.15 & 0.5636 \\
\hline $\begin{array}{l}\text { Geophilus truncorum } \\
\text { Coleoptera }\end{array}$ & 150 & 0.10 & 0.93 & 0.96 & 0.99 & 0.34 & 0.3650 \\
\hline Aleochara bipustulata & 118 & 0.76 & 0.76 & 0.77 & 0.82 & -0.08 & 0.7781 \\
\hline Amischa analis & 165 & 0.50 & 0.97 & 0.98 & 1.00 & -0.01 & 0.9545 \\
\hline Anisodactylus binotatus & 154 & 0.69 & 0.99 & 1.00 & 1.00 & -0.03 & 0.9271 \\
\hline Calosoma olivieri & 280 & 0.52 & 0.94 & 0.95 & 0.96 & -0.03 & 0.9233 \\
\hline Chaetocnema hortensis & 300 & 0.10 & 0.97 & 0.97 & 1.00 & 0.06 & 0.8362 \\
\hline Cordalia obscura & 257 & 0.51 & 0.99 & 0.99 & 1.00 & 0.33 & 0.1792 \\
\hline Epuraea biguttata & 111 & 0.32 & 0.94 & 0.95 & 0.99 & -0.46 & 0.1834 \\
\hline Heteroderes azoricus & 590 & 0.11 & 0.98 & 0.98 & 1.00 & -0.35 & 0.2703 \\
\hline Hirticomus quadriguttatus & 240 & 0.10 & 1.00 & 1.00 & 1.00 & 0.40 & 0.2224 \\
\hline Ocypus (Pseudocypus) aethiops & 128 & 0.60 & 0.90 & 0.90 & 0.94 & -0.07 & 0.6769 \\
\hline Pseudoophonus rufipes & 226 & 0.45 & 0.99 & 0.99 & 1.00 & -0.28 & 0.4024 \\
\hline Pterostichus (Argutor) vernalis & 69 & 0.43 & 0.97 & 0.97 & 0.99 & -0.21 & 0.4909 \\
\hline Rugilus orbiculatus orbiculatus & 233 & 0.18 & 0.98 & 0.98 & 1.00 & 0.20 & 0.4493 \\
\hline Sericoderus lateralis & 126 & 0.33 & 0.98 & 0.98 & 1.00 & 0.63 & 0.0485 \\
\hline Sitona discoideus & 98 & 0.27 & 0.96 & 0.96 & 0.99 & 0.02 & 0.9518 \\
\hline Sphenophorus abbreviatus & 153 & 0.18 & 0.93 & 0.94 & 1.00 & 0.54 & 0.0862 \\
\hline Stelidota geminata & 170 & 0.10 & 0.94 & 0.94 & 0.99 & 0.25 & 0.3620 \\
\hline Typhaea stercorea & 460 & 0.10 & 0.98 & 0.98 & 1.00 & -0.02 & 0.9390 \\
\hline $\begin{array}{l}\text { Xantholinus longiventris } \\
\text { Dermaptera }\end{array}$ & 549 & 0.15 & 0.99 & 0.99 & 1.00 & 0.40 & 0.1402 \\
\hline $\begin{array}{l}\text { Forficula auricularia } \\
\text { Diplopoda }\end{array}$ & 307 & 0.38 & 0.99 & 0.99 & 1.00 & 0.00 & 0.9968 \\
\hline Cylindroiulus propinquus & 547 & 0.15 & 0.97 & 0.97 & 1.00 & 0.38 & 0.0236 \\
\hline $\begin{array}{l}\text { Polydesmus coriaceus } \\
\text { Hemiptera }\end{array}$ & 115 & 0.37 & 0.98 & 0.97 & 1.00 & 0.18 & 0.3402 \\
\hline Anoscopus albifrons & 385 & 0.12 & 0.98 & 0.97 & 0.99 & 0.20 & 0.3377 \\
\hline Aphrodes hamiltoni & 380 & 0.10 & 0.97 & 0.98 & 1.00 & 0.07 & 0.6726 \\
\hline $\begin{array}{l}\text { Nabis pseudoferus ibericus } \\
\text { Pseudoescropiones }\end{array}$ & 73 & 0.71 & 0.96 & 0.96 & 0.99 & 0.11 & 0.7136 \\
\hline Chthonius ischnocheles & 180 & 0.53 & 0.94 & 0.94 & 0.99 & -0.12 & 0.5039 \\
\hline $\begin{array}{l}\text { Chthonius tetrachelatus } \\
\text { Opiliones }\end{array}$ & 127 & 0.14 & 0.72 & 0.73 & 0.80 & 0.37 & 0.1782 \\
\hline Homalenotus coriaceus & 124 & 0.31 & 0.97 & 0.98 & 1.00 & 0.51 & 0.0172 \\
\hline
\end{tabular}


Five categories of maps were included, and were used as predictors:

i. A digital elevation model (DEM) and derived maps. A raster DEM was developed by interpolating the elevation curves of the Digital Chart developed by the Cartographic Service of the Portuguese Army. We extracted mean and minimum elevation. The standard deviation of elevation in each $500 \times 500 \mathrm{~m}$ grid was calculated as a measure of topographic ruggedness.

ii. Climate data obtained from the CIELO Model (Azevedo 1996, Azevedo et al. 1999), developed to simulate local climate in island environments. CIELO is a physically based model that simulates the climatic variables on an island using data from the synoptic reference of a meteorological station. The domain of computation is a raster GIS parameterized with a DEM (see also Borges et al. 2006 for an application of such data). The CIELO model has been calibrated and validated for Terceira Island, and is now available through the CLIMAAT project (CLIMAAT Interreg_IIIB, MAC 2.3/A3, Azevedo 2003). The variables extracted were annual potential evapotranspiration, mean annual temperature and mean annual precipitation.

iii. Volcanic island map from the work of Victor Hugo Forjaz and colleagues (Forjaz 2004) that describes in detail all the volcanic systems of Terceira and all other Azorean islands. A categorical map was created with a total of 25 volcanic systems.

iv. Concerning land-use cover, we used the recently available habitat classification for Terceira Island (F. Dinis unpubl. data). The main land-uses are native forest (mainly composed of Laurisilva forest), semi-natural grassland, intensive pasture, exotic forest, urban areas, vines/orchards, abandoned fields and unproductive areas. The percentage of each land use in each $500 \times 500$ grid cell was computed.

v. Two additional layers were obtained from the Digital Chart developed by the Cartographic Service of the Portuguese Army: presence of water sources (rivers and lakes) and distance to urban areas.
The strong environmental gradient of Terceira Island, from high (wet and cold) to low (dry and hot) elevations, makes topographic and climatic variables highly correlated. To simplify these data, a principal components analysis (PCA) was constructed using the standardized normal scores of mean and minimum altitude and the three climate variables. PCA analysis selected one component (herein called climatic factor) with an eigenvalue higher than 1 (4.8) which explained 96.5\% of total variance in the climatic and topographic data. While the climatic factor describes the broad-scale environmental gradient of the island, the other variables refer to characteristics of the environment that do not show such broad spatial patterns (topographic ruggedness, presence of water sources), to historic events (volcanic systems) or to land use/habitat type (landuse cover, presence of water sources). Thus, the climatic factor was used to characterise the Grinnellian niche of the species (sensu Soberón 2007) and to produce estimations of their potential distributions; the other variables were used to estimate the real distributions.

\section{Modelling presence/absence data}

Presence/absence data were modelled using artificial neural networks (ANN), a machine-learning method able to deal with non-linear relationships between the dependent variable and the predictors and able to account for complex data (Olden et al. 2008, Özesmi et al. 2006a, Recknagel 2001, Venables \& Ripley 2002). ANNs have proved to outperform other conventional techniques in species distribution modelling studies (e.g. Olden \& Jackson 2002, Segurado \&Araújo 2004).

In this study, a Multi-Layer Perceptron (feedforward neural network with back propagation for training, Isasi Viñuela \& Galván León 2004) with one hidden layer was used (Fig. 1). Neurons are organized in different layers: an input layer, a hidden layer and an output layer. The input layer has a number of neurons equal to the number of independent variables, while the output layer has only one neuron. The hidden layer contains 15 neurons to achieve a trade off between predictive accuracy and overfitting (A. Jiménez-Val- 


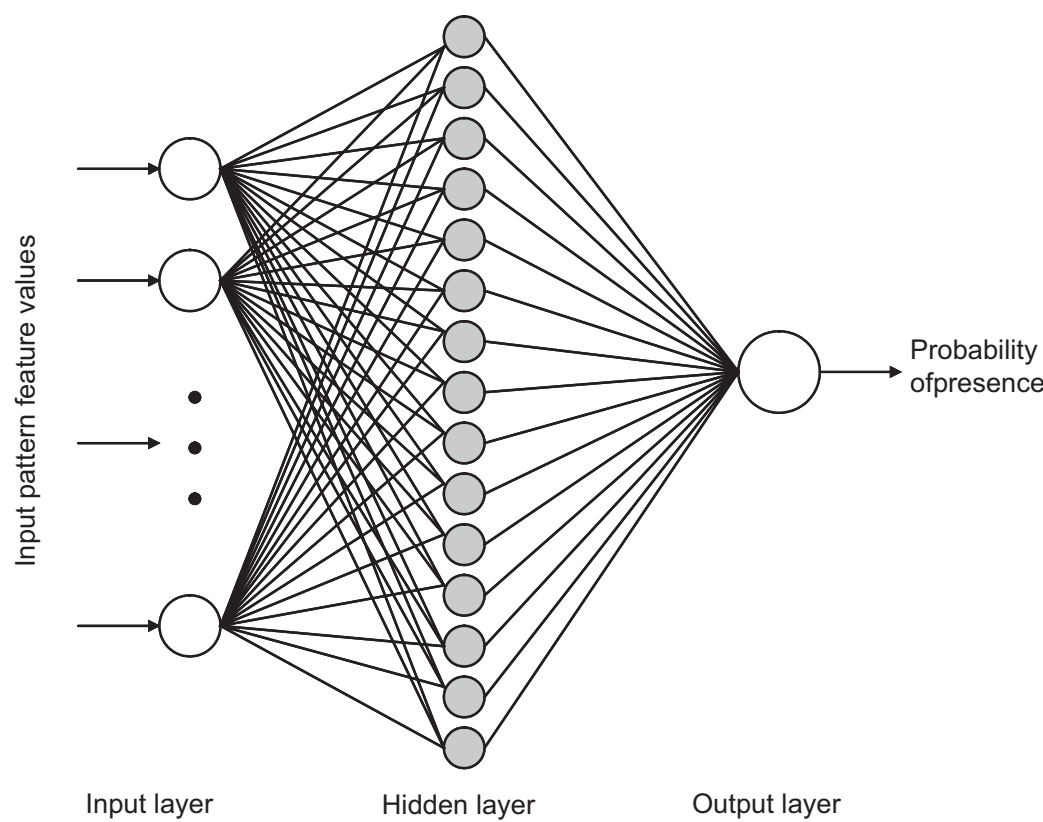

Fig. 1. Architecture of the Multi-Layer Perceptron used in this study. In the case of the potential distribution, one neuron forms the input layer; for real distributions 13 neurons formed the input layer. verde unpubl. data). Each neuron is connected by axons to all neurons of the next layer in a unidirectional way, and the intensity of the signal is defined by the weight assigned to each connexion. Thus, the state of the hidden neurons is defined by the weighted sum of the inputs and an activation non-linear function (logistic function in this study). Initial weights were set to 0.1 . In the training process, weights are changed iteratively (maximum number of iterations $=2000$ ) to minimize the least-square error function. Thus, a Multi-Layer Perceptron with one hidden layer basically performs a linear combination of sigmoid function of the inputs. For further details see, for example, Ripley (1996), Isasi Viñuela and Galván León (2004) and Özesmi et al. (2006b). Neural networks were fitted in R ( R Development Core Team 2004) using the nnet package (Venables \& Ripley 2002).

Two kinds of models were developed for every species, each using a different type of absence information and different predictor variables to account for both extremes of the potential-actual distribution gradient (see Soberon \& Peterson 2005 and Jiménez-Valverde et al. 2008 for an extensive conceptual framework):

1. In order to account for the potential distribution (climate-related potentiality), we tabu- lated maximum and minimum values of the climatic factor at presence points (presences from the BALA survey and ATLANTIS database), so defining the climate envelope for each of the 48 species (Busby 1991, Lobo et al. 2006). From the area outside the envelope, probable absences were randomly selected to generate training datasets with prevalence as low as 0.1 (i.e., number of presences/[number of presences + number of absences] $=0.1$ ) for each species if possible (Jiménez-Valverde \& Lobo 2006b, 2007a). In the modelling process, only the climatic factor was used as predictor, as including other variables would imply accounting for factors that restrict potential distributions to realized ones (see above).

2. To account for the real distribution, presences from the BALA survey and ATLANTIS database and absences obtained in the BALA transects were used (real absences). In this case, all 13 (including the climatic factor) variables were used in the modelling process to introduce historical and anthropogenic factors in the models (see above).

\section{Model evaluation}

Models were evaluated using a 'leave-one-out' 
jackknife approach: that is, one observation was excluded, the model parameterized with the remaining $n-1$ observations, a predicted probability is obtained for the excluded observation, and the procedure is repeated $n$ times (Olden et al. 2002). With these new jackknife probabilities, the area under the ROC curve (AUC), a measure of overall discriminatory power (Swets 1988, Fielding \& Bell 1997), was computed (but see recent criticisms of this measure in Lobo et al. 2008 and Peterson et al. 2008). Also, sensitivity (presences correctly predicted) and specificity (absences correctly predicted) were calculated using the threshold which minimizes their difference (Jiménez-Valverde \& Lobo 2006c, 2007b). Notice that potential distribution models will unavoidably show high values of discrimination capacity (see Jiménez-Valverde \& Lobo 2007a). All evaluation computations were run in $R$ ( $R$ Development Core Team 2004) using the ROCR package (Sing et al.2005) and custom scripts.

\section{Relationship between probability of presence and abundance}

Spearman rank correlations between predicted probabilities of presence (from potential and real distribution models) and observed abundance data from locations with values $>0$ were calculated. Positive correlations including 0 data points indicating absence would mean good discrimination capacity of presence/ absence models, but not necessarily good capacity to explain variation in abundance. In total, $48 \times 2$ independent correlation analyses were performed. No $\alpha$-adjustment method for multiple tests was applied, to avoid increasing type II errors (the probability of accepting the null hypothesis when the alternative is true; Perneger 1998, Moran 2003, Gotelli \& Ellison 2004). Then, we studied if there was a relationship between Spearman correlation coefficients $\left(r_{\mathrm{s}}\right)$ and $p$ values with mean abundances (see Appendix) and the number of occupied sites by each species, as well as if there was any difference in $r_{\mathrm{s}}$ scores and $p$ values between Araneae (high vagile taxa) and Coleoptera (low vagile taxa; note that the concepts of high and low vagility are relative).

\section{Results}

All models of the potential distribution showed high predictive power, with small variation in accuracy measures (Table 1). The mean discrimination AUC score was 0.99 , being higher than 0.8 in all cases, which indicates that the models are highly discriminatory (Swets 1988). This means that, in the worst model, a presence will be predicted as having a higher probability than an absence $80 \%$ of the time. Sensitivity and specificity were quite high, with mean values of 0.96 , higher than 0.72 in all cases. Only eight models showed probabilities of presence significantly correlated with abundance (Dysdera crocota, Erigone autumnalis, Erigone dentipalpis, Oedothorax fuscus, Prinerigone vagans, Sericoderus lateralis, Homalenotus coriaceus, and Cylindroiulus propinquus) at $p<0.05$, only one of them significant at $p<0.01$ (Erigone dentipalpis). The discrimination capacity of the models does not affect the relationship as $r_{\mathrm{s}}$ scores were not correlated with AUC values $\left(r=0.08^{\mathrm{ns}}\right)$. No significant correlation was found between neither mean abundance nor the number of occupied sites and $r_{\mathrm{s}}$ scores $\left(r=0.14^{\mathrm{ns}}\right.$ and $r=0.19^{\mathrm{ns}}$, respectively). $P$ values were not correlated with mean abundance or the number of occupied sites either ( $r=-0.20^{\text {ns }}$ and $r=-0.22^{\text {ns }}$, respectively). Mean $r_{\mathrm{s}}$ scores were higher in Araneae (mean \pm $\mathrm{SD}=0.214 \pm 0.333)$ than in Coleoptera $(0.068$ $\pm 0.299)$ but the difference was not statistically significant $(t=1.371, p=0.180) . P$ values were significantly lower in Araneae than in Coleoptera (Mann-Whitney $U$-test: $Z=-2.924, p=0.004$ ).

On the contrary, real distribution predictions were not as accurate as the potential ones and showed higher variation in accuracy measures (Table 2). The mean AUC value was 0.74, with 33 species showing AUC scores $\geq 0.70$, indicating useful models (Swets 1988). Mean values of sensitivity and specificity were both 0.70 . Only Erigone autumnalis and Geophilus truncorum showed significant correlations between probability of presence and abundance at $p<0.05$, only one of them significant at $p<0.01$ (Erigone autumnalis). Again, the discrimination capacity of the models does not affect the relationship as $r_{\mathrm{s}}$ scores were not correlated with AUC values $\left(r=-0.25^{\mathrm{ns}}\right)$. No significant correlations 
Table 2. Characteristics of the training data for the real distribution models (sample size and prevalence), accuracy statistics (sensitivity, specificity and AUC) and results of the correlation analysis between probability of occurrence and abundance ( $r_{\mathrm{s}}$ and $p$ values).

\begin{tabular}{|c|c|c|c|c|c|c|c|}
\hline Species & Sample size & Prevalence & Sensitivity & Specificity & AUC & $r_{\mathrm{s}}$ & $p$ \\
\hline \multicolumn{8}{|l|}{ Araneae } \\
\hline Agyneta decora & 85 & 0.45 & 0.63 & 0.64 & 0.68 & -0.27 & 0.3408 \\
\hline Dysdera crocata & 145 & 0.85 & 0.62 & 0.64 & 0.67 & -0.17 & 0.2686 \\
\hline Eperigone bryantae & 112 & 0.60 & 0.61 & 0.62 & 0.65 & 0.35 & 0.1856 \\
\hline Eperigone fradeorum & 90 & 0.37 & 0.61 & 0.61 & 0.67 & -0.06 & 0.8537 \\
\hline Erigone atra & 81 & 0.48 & 0.49 & 0.48 & 0.50 & 0.40 & 0.1584 \\
\hline Erigone autumnalis & 96 & 0.60 & 0.67 & 0.68 & 0.76 & 0.63 & 0.0003 \\
\hline Erigone dentipalpis & 97 & 0.60 & 0.72 & 0.72 & 0.78 & 0.12 & 0.5650 \\
\hline Ero furcata & 86 & 0.53 & 0.61 & 0.60 & 0.59 & -0.08 & 0.7356 \\
\hline Lepthyphantes acoreensis & 82 & 0.55 & 0.76 & 0.76 & 0.81 & 0.15 & 0.4707 \\
\hline Meioneta fuscipalpis & 80 & 0.33 & 0.77 & 0.78 & 0.81 & 0.54 & 0.0696 \\
\hline Oedothorax fuscus & 100 & 0.74 & 0.65 & 0.65 & 0.72 & 0.19 & 0.3135 \\
\hline Ostearius melanopygius & 111 & 0.54 & 0.80 & 0.80 & 0.82 & 0.03 & 0.9183 \\
\hline Pachygnatha degeeri & 84 & 0.37 & 0.84 & 0.83 & 0.87 & -0.32 & 0.2424 \\
\hline Palliduphantes schmitzi & 83 & 0.49 & 0.66 & 0.67 & 0.70 & 0.02 & 0.9420 \\
\hline Pardosa acoreensis & 135 & 0.90 & 0.57 & 0.57 & 0.62 & 0.20 & 0.1670 \\
\hline Porrhomma borgesi & 74 & 0.31 & 0.65 & 0.67 & 0.75 & 0.05 & 0.8799 \\
\hline Prinerigone vagans & 103 & 0.53 & 0.73 & 0.73 & 0.78 & 0.34 & 0.1535 \\
\hline $\begin{array}{l}\text { Rugathodes acoreensis } \\
\text { Blattaria }\end{array}$ & 75 & 0.51 & 0.84 & 0.84 & 0.89 & -0.01 & 0.9565 \\
\hline $\begin{array}{l}\text { Zetha vestita } \\
\text { Chilopoda }\end{array}$ & 73 & 0.62 & 0.71 & 0.71 & 0.78 & -0.33 & 0.1935 \\
\hline $\begin{array}{l}\text { Geophilus truncorum } \\
\text { Coleoptera }\end{array}$ & 66 & 0.23 & 0.53 & 0.51 & 0.56 & 0.70 & 0.0254 \\
\hline Aleochara bipustulata & 129 & 0.68 & 0.81 & 0.80 & 0.85 & -0.05 & 0.8562 \\
\hline Amischa analis & 116 & 0.69 & 0.75 & 0.75 & 0.85 & -0.09 & 0.7015 \\
\hline Anisodactylus binotatus & 152 & 0.69 & 0.73 & 0.72 & 0.80 & 0.02 & 0.9562 \\
\hline Calosoma olivieri & 186 & 0.77 & 0.76 & 0.76 & 0.85 & -0.51 & 0.0918 \\
\hline Chaetocnema hortensis & 73 & 0.41 & 0.70 & 0.70 & 0.75 & 0.14 & 0.6386 \\
\hline Cordalia obscura & 162 & 0.78 & 0.80 & 0.81 & 0.90 & 0.19 & 0.4480 \\
\hline Epuraea biguttata & 85 & 0.42 & 0.69 & 0.69 & 0.73 & 0.16 & 0.4731 \\
\hline Heteroderes azoricus & 109 & 0.55 & 0.95 & 0.96 & 0.99 & -0.30 & 0.3458 \\
\hline Hirticomus quadriguttatus & 74 & 0.32 & 0.92 & 0.92 & 0.97 & 0.24 & 0.4789 \\
\hline Ocypus (Pseudocypus) aethiops & 91 & 0.85 & 0.44 & 0.43 & 0.41 & 0.19 & 0.2349 \\
\hline Pseudoophonus rufipes & 150 & 0.67 & 0.78 & 0.78 & 0.84 & -0.12 & 0.7269 \\
\hline Pterostichus (Argutor) vernalis & 74 & 0.41 & 0.70 & 0.70 & 0.76 & -0.16 & 0.6069 \\
\hline Rugilus orbiculatus orbiculatus & 85 & 0.51 & 0.70 & 0.69 & 0.75 & 0.00 & 0.9962 \\
\hline Sericoderus lateralis & 95 & 0.43 & 0.80 & 0.81 & 0.82 & 0.29 & 0.4082 \\
\hline Sitona discoideus & 70 & 0.37 & 0.65 & 0.66 & 0.69 & 0.19 & 0.5450 \\
\hline Sphenophorus abbreviatus & 79 & 0.35 & 0.71 & 0.73 & 0.76 & 0.60 & 0.0509 \\
\hline Stelidota geminata & 61 & 0.28 & 0.53 & 0.52 & 0.50 & -0.21 & 0.4408 \\
\hline Typhaea stercorea & 93 & 0.49 & 0.91 & 0.91 & 0.97 & -0.19 & 0.5257 \\
\hline $\begin{array}{l}\text { Xantholinus longiventris } \\
\text { Dermaptera }\end{array}$ & 120 & 0.68 & 0.71 & 0.71 & 0.74 & 0.20 & 0.4630 \\
\hline $\begin{array}{l}\text { Forficula auricularia } \\
\text { Diplopoda }\end{array}$ & 157 & 0.74 & 0.80 & 0.80 & 0.88 & 0.23 & 0.4303 \\
\hline Cylindroiulus propinquus & 96 & 0.83 & 0.75 & 0.75 & 0.78 & 0.03 & 0.8744 \\
\hline $\begin{array}{l}\text { Polydesmus coriaceus } \\
\text { Hemiptera }\end{array}$ & 67 & 0.64 & 0.49 & 0.50 & 0.48 & 0.12 & 0.5081 \\
\hline Anoscopus albifrons & 76 & 0.61 & 0.43 & 0.43 & 0.46 & 0.29 & 0.1563 \\
\hline Aphrodes hamiltoni & 56 & 0.68 & 0.84 & 0.83 & 0.94 & 0.06 & 0.7301 \\
\hline $\begin{array}{l}\text { Nabis pseudoferus ibericus } \\
\text { Pseudoescropiones }\end{array}$ & 94 & 0.52 & 0.67 & 0.67 & 0.73 & -0.03 & 0.9140 \\
\hline Chthonius ischnocheles & 114 & 0.82 & 0.63 & 0.65 & 0.68 & 0.00 & 0.9770 \\
\hline $\begin{array}{l}\text { Chthonius tetrachelatus } \\
\text { Opiliones }\end{array}$ & 62 & 0.29 & 0.67 & 0.66 & 0.66 & -0.01 & 0.9742 \\
\hline Homalenotus coriaceus & 73 & 0.53 & 0.64 & 0.65 & 0.71 & 0.39 & 0.0775 \\
\hline
\end{tabular}


were found between neither mean abundance nor the number of occupied sites and $r_{\mathrm{s}}$ scores $\left(r=0.07^{\mathrm{ns}}\right.$ and $r=0.04^{\mathrm{ns}}$, respectively). $P$ values were not correlated with mean abundance or the number of occupied sites either $\left(r=-0.13^{\text {ns }}\right.$ and $r=-0.08^{\text {ns }}$, respectively). Mean $r_{\text {s }}$ scores were higher in Araneae (mean $\pm \mathrm{SD}=0.117 \pm 0.262)$ than in Coleoptera $(0.031 \pm 0.254)$, although the difference was not statistically significant $(t=$ $1.016, p=0.317) . P$ values were not significantly lower in Araneae than in Coleoptera (MannWhitney $U$-test: $Z=-0.881, p=0.378$ ).

\section{Discussion}

\section{General trends}

As in previous analyses (Pearce \& Ferrier 2001, Nielsen et al. 2005), for most species analysed, we did not find a significant relationship between local probability of occurrence and local abundance. However, for eight exotic and one native species (see Appendix), we found probabilities of presence significantly correlated with density. No relation with mean abundance or number of occupied sites was found, but there is a tendency for vagile species (spiders) to show more apparent relationships between probability of occurrence and abundance. In fact, five out of nine significant cases were spiders. Spiders show a great dispersal capacity, as suggested by the fact that due to passive air dispersal using silk threads (ballooning), they can be found in the air at high altitudes (Freeman 1946) and are among the first colonizers of islands (Edwards \& Thornton 2001). This characteristic, together with being generalist predators (Wise 1993), may result in spiders being in a higher degree of equilibrium with the environment than other taxa, something that, as explained in more detail in the next section, would enhance the relationship between probability of occurrence and local abundance.

\section{Concrete cases}

The five spider species for which significant correlations were found are widely distributed in anthropogenic Azorean habitats, namely inten- sive pasture (see Borges \& Brown 2001, 2004). The five spider species are well adapted pasturedwelling spiders, at least four of which (Prinerigone vagans, Erigone dentipalpis, Erigone autumnalis and Oedothorax fuscus) normally occur in heavily grazed pastures (De Keer \& Maelfait 1988, Borges \& Brown 2001). Borges and Brown (2001) showed that in Azorean intensive and semi-natural pastureland, diverse and structurally complex pasture sites supported more individual web-building spiders per unit area than less complex ones. In fact, physical complexity of the grassland and sub-shrub vegetation layers has been pointed out as one of the most important deterministic factors of spider distribution, especially for web-building species (Grill et al. 2005, Jiménez-Valverde \& Lobo 2007c and references therein). Probably the most direct effect of habitat complexity is the availability of a greater number of microniches (Jiménez-Valverde \& Lobo 2007c). Azorean pastures are usually organized into small (around $100 \times 100 \mathrm{~m}$ ) stone-fenced fields grazed regularly (every three weeks in the summer months) by milk cattle. Therefore, the landscape is organized in a mosaic of recently grazed fields either with or without cows and with high structural heterogeneity of vegetation, thus providing suitable conditions in terms of habitat structure throughout most of Terceira. Moreover, Erigonidae is the family most common in aeroplankton samples (Dean \& Sterling 1985, Bishop 1990), indicating a huge capacity for long-distance dispersal and, thus, for reaching and establishing in pastures with high habitat complexity. This, together with the fact that all the spiders were sampled between grazing periods when the grass reaches its highest density, suggests that habitat structure is not a limiting factor in spider populations. Also, pastures are highly productive ecosystems (Curry 1994), so these spider species live in habitats with high food availability, probably indirectly related to the climatic gradient of the island. These factors suggest that the patchy distribution of resources in the Azorean mosaic pastureland favours the strength of the relationship between occurrence and abundance for these habitat specialist species (see also Nielsen et al. 2005), together with the fact that no other factor except food availability appears to be a major determinant of their abun- 
dance at this scale (see Wise 1993: chapter 2). In fact, significant relationships are mostly found when modelling the potential distribution, i.e., when only the climatic factor is used as explanatory variable and so the probability of occurrence may reflect climatic favourability.

Besides the tendency observed for spiders, four other arthropod species pertaining to different taxa and with different characteristics showed positive relationships between the probability of occurrence and abundance. Cylindroiulus propinquus (Diplopoda) and Homalenotus coriaceus (Opiliones) are common arthropod species in several Azorean native and altered habitats, but not particularly common in intensive pastures. Geophilus truncorum (Chilopoda) is mainly a forest species and Sericoderus lateralis (Coleoptera) is one of the most common beetles in most habitats in the Azores.

\section{Why is the probability of occurrence not predicting abundance?}

Despite the generally observed trend for spiders to show a positive relationship between predicted occurrence and abundance, the probability of occurrence was a poor predictor of local abundance for most species. In fact, for other species with the same characteristics as the ones for which significant relations have been found, we observed no capacity to account for abundance in their occurrence models. Instead, other variables, such as site history, scale or species life history may have influenced the spatial variation in local abundance of Azorean epigean arthropod species. That many other arthropod species have wide distributions on the island suggests that their local abundance arises from non-environmental controls of density (Van Horne 1983), rather than on their ability to reach and occupy potential habitats.

The adequate sampling of arthropods in space and time is a very hard task (Jones and Eggleton 2000, Jiménez-Valverde \& Lobo 2006a, Cardoso et al. 2007). Additionally, usually only one-year abundance estimations are available for a number of sites. However, arthropod populations are known to fluctuate markedly over time (Stewart-Oaten et al. 1995, Heller et al. 2006).
These fluctuations may not depend on environmental factors but rather on demographic ones, including demographic stochasticity, finally altering occupancy patterns (Hanski 1999) and may dilute the probability of a significant occurrencedensity relationship in many species (Nielsen et al. 2005). Thus, it could be argued that, although the relationship between presence/abundance exists for many other species under ideal conditions, difficulties in the estimation of density results in the lack of recognition of the pattern. However, we do not believe this methodological drawback to be determining our results as the model of abundance-variance-occupancy of $\mathrm{He}$ and Gaston (2003) fits very well to the same abundance used in our study (Gaston et al. 2006), supporting the robustness of the data.

All these considerations are based on the assumption that occurrence models reflect habitat suitability. First, source-sink dynamics (sensu Shmida \& Wilson 1985) explains how a species can occur in unsuitable places, maintaining populations due to immigration (Shmida \& Wilson 1985, Pulliam 2000). Relocation to suboptimal habitats can be observed if the suitable environment is scarce (Braunisch et al. 2008). Additionally, dispersal limitation can explain how absences can be found in environmentally suitable places (Pulliam 2000). Second, and more importantly from a conceptual point of view, the modelling objective changes depending on the nature of the absence and the predictors used (Soberón \& Peterson 2005, Jiménez-Valverde et al. 2008). When climatic variables and probable absences located outside the envelope defined by those predictors are used, the models are probably forecasting the potential niche concept in a Grinnellian sense (our potential distribution approach; Soberón 2007). However, if real absences and/or variables that account for historical or human disturbance events are used, then the models may approach the real geographic distribution (our real distribution approach). If, as in the case of the Azorean arthropod fauna, species are highly influenced by land-use variables, then these variables will force the algorithm in such a way that the climatic factors lose relevance and climatic suitability may be diluted. That is, we would be generating a geographical range map rather than an environmental suitability map. As 
a consequence, the relationship between probability of occurrence and abundance will be lost, as our results for potential vs. real distribution models indicate. Besides, even potential distribution models based on non-causal correlative relationships are hardly able to describe the fundamental niche of the species (Kearney \& Porter 2009). Hence, their interpretation in terms of environmental suitability may be questioned.

\section{Conclusions}

Generally, the spatial distribution of individuals is fundamental to understanding macroecological patterns (Gaston 1996). Our analyses have shown that, although there is a tendency for spiders (vagile species and generalist predators) to show relationships between probability of occurrence and local abundance, this is weak and there is no general applicability of the pattern. Species for which the relation holds are difficult to identify a priori, so using environmental suitability (i.e., probability of presence) as a surrogate for arthropod relative local abundance estimates should be ruled out; abundance is a quite variable parameter which depends on many factors apart from environment. Consequently, despite the relatively easy access of occurrence data and the straightforward application of distribution modelling techniques, the use of occurrence models as density indicators of the relative population size of arthropod species cannot be generalized. Finally, although the way occurrence models are built is critical as it will determine the concept being modelled, i.e., environmental potential vs. realized geographical distribution, they may not reflect environmental suitability.

\section{Acknowledgements}

A. Townsend Peterson, Jorge M. Lobo, Valerie K. Brown, Kevin J. Gaston and the people from the Journal Club of the BIOCHANGE Lab (Museo Nacional de Ciencias Naturales, Spain) kindly commented on an early version of the manuscript. This work was supported by funding to A.J.V. and P.A.V.B. from CITA-A. F.D. was supported by Fundação para a Ciência e a Tecnologia, BD/13197/2003. E.B. Azevedo was supported by project CLIMAAT-Interreg IIIb MAC 2.3/A3 co-financed by the European Union under Program FEDER. Funding for field data collecting was provided by "Direcção Regional dos Recursos Florestais" ("Secretaria Regional da Agricultura e Pescas") through the Project "Reservas Florestais dos Açores: Cartografia e Inventariação dos Artrópodes Endémicos dos Açores" (PROJ. 17.01080203). Presence-absence data from ATLANTIS database comes from the Projects INTERREG IIIB ATLANTICO and BIONATURA. The CIELO model was provided by the CITAA from the University of the Azores, through the SIgCHCRUS project (FCT-POCTI/CTA/1954/2001).

\section{References}

Albert, C. \& Thuiller, W. 2008: Favourability functions versus probability of presence: advantages and misuses. - Ecography 31: 417-422.

Araújo, M. B. \& Williams, P. H. 2000: Selecting areas for species persistence using occurrence data. - Biological Conservation 96: 331-345.

Azevedo, E. B. 1996: Modelação do Clima Insular à Escala Local. Modelo CIELO aplicado à ilha Terceira. - Ph.D. thesis, Universidade dos Açores, Angra do Heroísmo.

Azevedo, E. B. 2003: Projecto CLIMAAT - Clima e Meteorologia dos Arquipélagos Atlanticos. - PIC Interreg_IIIB-Mac 2.3/A3.

Azevedo, E. B., Pereira, L. S. \& Itier, B. 1999: Modelling the local climate in island environments: water balance applications. - Agricultural Water Management 40: 393-403.

Barbosa, A. M., Real, R., Olivero, J. \& Vargas, J. M. 2003: Otter (Lutra lutra) distribution modeling at two resolution scales suited to conservation planning in the Iberian Peninsula. - Biological Conservation 114: 377-387.

Bishop, L. 1990: Meteorological aspects of spiders balloning. - Environmental Entomology 19: 1381-1387.

Borges, P. A. V. 2005: Introduction. - In: Borges, P. A. V., Cunha, R., Gabriel, R., Martins, A. M. F., Silva, L. \& Vieira, V. (eds.), A list of the terrestrial fauna (Mollusca and Arthropoda) and flora (Bryophyta, Pteridophyta and Spermatophyta) from the Azores: 11-20. Direcção Regional de Ambiente and Universidade dos Açores, Horta, Angra do Heroísmo and Ponta Delgada.

Borges, P. A. V. \& Brown, V. K. 2001: Phytophagous insects and web-building spiders in relation to pasture vegetation complexity. - Ecography 24: 68-82.

Borges, P. A. V. \& Brown, V. K. 2004: Arthropod community structure in pastures of an island archipelago (Azores): looking for local-regional species richness patterns at small-scales. - Bulletin of Entomological Research 94: 111-121.

Borges, P. A. V., Aguiar, C., Amaral, J., Amorim, I. R., André, G., Arraiol, A., Baz, A., Dinis, F., Enghoff, H., Gaspar, C., Ilharco, F., Mahnert, V., Melo, C., Pereira, F., Quartau, J. A., Ribeiro, S., Ribes, J., Serrano, A. R. M., Sousa, A. B., Strassen, R. Z., Vieira, L., Vieira, V., Vitorino, A. \& Wunderlich, J. 2005a: Ranking protected areas in the Azores using standardized sampling of soil epigean arthropods. - Biodiversity and Conservation 14: 2029-2060.

Borges, P. A. V., Vieira, V., Dinis, F. \& Jarroca, S. 2005b: List of Arthropods (Arthropoda). - In: Borges, P. A. 
V., Cunha, R., Gabriel, R., Martins, A. M. F., Silva, L. \& Vieira, V. (eds.), A list of the terrestrial fauna (Mollusca and Arthropoda) and flora (Bryophyta, Pteridophyta and Spermatophyta) from the Azores: 163-221. Direcção Regional de Ambiente and Universidade dos Açores, Horta, Angra do Heroísmo and Ponta Delgada.

Borges, P. A. V., Lobo, J. M., Azevedo, E. B., Gaspar, C., Melo, C. \& Nunes, L. V. 2006: Invasibility and species richness of island endemic arthropods: a general model of endemic vs. exotic species. - Journal of Biogeography 33: 169-187.

Borges, P. A. V., Ugland, K. I., Dinis, F. O. \& Gaspar, C. 2008: Insect and spider rarity in an oceanic island (Terceira, Azores): true rare and pseudo-rare species. - In: Fattorini, S. (ed.), Insect ecology and conservation: 47-70. Research Signpost.

Boyce, M. S. \& McDonald, L. L. 1999: Relating populations to habitats using resource selection functions. - Trends in Ecology and Evolution 14: 268-272.

Braunisch, V., Bollmann, K., Graf, R. F. \& Hirzel, A. H. 2008: Living on the edge - modelling habitat suitability for species at the edge of their fundamental niche. Ecological Modelling 214: 153-167.

Busby, J. R. 1991: BIOCLIM: A bioclimate analysis and prediction system. - In: Margules, C. R. \& Austin, M. P. (eds.), Nature conservation: cost effective biological surveys and data analysis: 64-68. CSIRO, Australia.

Cardoso, P., Lobo, J. M., Calvo, S., Dinis, F., Gaspar, C. \& Borges, P. A. V. 2009: A spatial scale assessment of habitat effects on arthropod communities of an oceanic island. - Acta Oecologica 35: 590-597.

Cardoso, P., Silva, I., Oliveira, N. G. \& Serrano, A. M. 2007: Seasonality of spiders (Araneae) in Mediterranean ecosystems and its implications in the optimum sampling period. - Ecological Entomology 32: 516-526.

Conrad, K. F., Warren, M. S., Fox, M., Parsons, M. S. \& Woiwod, I. P. 2006: Rapid declines of common, widespread British moths provide evidence of an insect biodiversity crisis. - Biological Conservation 132: 279-291.

Curry, J. P. 1994: Grassland invertebrates - ecology, influence on soil fertility and effects on plant growth. Chapman \& Hall, London.

Curtis, D. J. 1980: Pitfalls in spider community studies (Arachnida: Araneae). - Journal of Arachnology 8: 271-280.

Dean, D. A. \& Sterling, W. L. 1985: Size and phenology of ballooning spiders at two locations in eastern Texas. Journal of Arachnology 13: 111-120.

De Keer, R. \& Maelfait, J.-P. 1988: Observations on the life cycle of Erigone atra Araneae, Erigoninae in a heavily grazed pasture. - Pedobiologia 32: 201-212.

Downie, I. S., Ribera, I., McCracken, D. I., Wilson, W. L., Foster, G. N., Waterhouse, A., Abernethy, V. J. \& Murphy, K. J. 2000: Modelling populations of Erigone atra and E. dentipalpis (Araneae: Linyphiidae) across an agricultural gradient in Scotland. - Agriculture, Ecosystems and Environment 80: 15-28.

Edwards, J. S. \& Thornton, W. B. 2001: Colonization of an island volcano, Long Island, Papua New Guinea, and an emergent island, Motmot, in its caldera lake. VI. The pioneer arthropod community of Motmot. - Journal of
Biogeography 28: 1379-1388.

Fielding, A. H. \& Bell, J. F. 1997: A review of methods for the assessment of prediction errors in conservation presence/absence models. - Environmental Conservation 24: 38-49.

Forjaz, V. H. (ed.) 2004: Atlas Básico dos Açores. - OVGA - Observatório Vulcanológico dos Açores, Ponta Delgada.

Freeman, J. A. 1946: The distribution of spiders and mites up to 300 feet in the air. - Journal of Animal Ecology 15: 69-74.

Gaston, K. J. 1996: The multiple forms of the interspecific abundance-distribution relationship. - Oikos 75: 211-220.

Gaston, K. J. \& Blackburn, T. M. 2000: Pattern and process in macroecology. - Blackwell Science, London.

Gaston, K. J., Borges, P. A. V., He, F. \& Gaspar, C. 2006: Abundance, spatial variance and occupancy: arthropod species distribution in the Azores. - Journal of Animal Ecology 75: 646-656.

Gotelli, N. J. \& Ellison, A. M. 2004: A primer of ecological statistics. - Sinauer Associates, Inc., MA, USA.

Grill, A., Knoflach, B., Cleary, D. F. R. \& Kati, V. 2005: Butterfly, spider, and plant communities in different land-use types in Sardina, Italy. - Biodiversity and Conservation 14: 1281-1300.

Hanski, I. 1999: Metapopulation ecology. - Oxford University Press, Oxford.

He, F. \& Gaston, K. J. 2003: Occupancy, spatial variance, and the abundance of species. - American Naturalist 162: 366-375.

Heller, N. E., Sanders, N. J. \& Gordon, D. M. 2006: Linking spatial and temporal scales in the study of an Argentine ant invasion. - Biological Invasions 8: 501-507.

Hirzel, A. H., Posse, B., Oggier, P.-A., Crettenand, Y., Glenz, C. \& Arlettaz, R. 2004: Ecological requirements of a reintroduced species, with implications for release policy: the bearded vulture recolonizing the Alps. Journal of Applied Ecology 41: 1103-1116.

Hortal, J., Borges, P. A. V., Dinis, F., Jiménez-Valverde, A., Chefaoui, R. M., Lobo, J. M., Jarroca, S., Azevedo, E. B., Rodrigues, C., Madruga, J., Pinheiro, J., Gabriel, R., Cota Rodrigues, F. \& Pereira, A. R. 2005: Using ATLANTIS - Tierra 2.0 and GIS environmental information to predict the spatial distribution and habitat suitability of endemic species. - In: Borges, P. A. V., Cunha, R., Gabriel, R., Martins, A. M. F., Silva, L. \& Vieira, V. (eds.), A list of the terrestrial fauna (Mollusca and Arthropoda) and flora (Bryophyta, Pteridophyta and Spermatophyta) from the Azores: 69-113. Direcção Regional de Ambiente and Universidade dos Açores, Horta, Angra do Heroísmo and Ponta Delgada.

Hortal, J., Borges, P. A. V. \& Gaspar, C. 2006: Evaluating the performance of species richness estimators: Sensitivity to sample grain size. - Journal of Animal Ecology 75: 274-287.

Hortal, J., Lobo, J. M. \& Jiménez-Valverde, A. 2007: Limitations of biodiversity databases: case study on seed-plant diversity in Tenerife (Canary Islands). - Conservation Biology 21: 853-863.

Isasi Viñuela, P. \& Galván León, I. M. 2004: Redes de Neuronas Artificiales. Un enfoque práctico. - Pearson 
Educación, Madrid.

Jiménez-Valverde, A. \& Lobo, J. M. 2006a: Establishing reliable spider (Araneae, Araneidae \& Thomisidae) assemblage sampling protocols: estimation of species richness, seasonal coverage and contribution of juvenile data to species richness and composition. - Acta Oecologica 30: 21-32.

Jiménez-Valverde, A. \& Lobo, J. M. 2006b: Distribution determinants of endangered Iberian spider Macrothele calpeiana (Araneae, Hexathelidae). - Environmental Entomology 35: 1491-1499.

Jiménez-Valverde, A. \& Lobo, J. M. 2006c: The ghost of unbalanced species distribution data in geographic model predictions. - Diversity and Distributions 12: 521-524.

Jiménez-Valverde, A. \& Lobo, J. M. 2007a: Potential distribution of the endangered spider Macrothele calpeiana (Walckenaer, 1805) (Araneae, Hexathelidae) and the impact of climate warming. - Acta Zoologica Sinica 53: 865-876.

Jiménez-Valverde, A. \& Lobo, J. M. 2007b: Threshold criteria for conversion of probability of species presence to either-or presence-absence. - Acta Oecologica 31: 361-369.

Jiménez-Valverde, A. \& Lobo, J. M. 2007c: Determinants of local spider (Araneidae \& Thomisidae) species richness on a regional scale: climate and altitude $v s$. habitat structure. - Ecological Entomology 32: 113-122.

Jiménez-Valverde, Lobo, J. M. \& Hortal, J. 2008: Not as good as they seem: the importance of concepts in species distribution modelling. - Diversity and Distributions 14: 885-890.

Jones, D. T. \& Eggleton, P. 2000: Termite species assemblages in tropical forests: testing a rapid biodiversity assessment protocol. - Journal of Applied Ecology 37: 191-203.

Joseph, L. N., Field, S. A., Wilcox, C. \& Possingham, H. P. 2006: Presence-absence versus abundance data for monitoring threatened species. - Conservation Biology 20: $1679-1687$.

Kearney, M. \& Porter, W. 2009: Mechanistic niche modelling: combining physiological and spatial data to predict species' ranges. - Ecology Letters 12: 334-350.

Lobo, J. M., Verdú, J. R. \& Numa, C. 2006: Environmental and geographical factors affecting the Iberian distribution of flightless Jekelius species (Coleoptera: Geotrupidae). - Diversity and Distributions 12: 179-188.

Lobo, J. M., Jiménez-Valverde, A. \& Real, R. 2008: AUC: A misleading measure of the performance of predictive distribution models. - Global Ecology and Biogeography 17: 145-151.

Luff, M. L. 1975: Some features influencing the efficiency of pitfall traps. - Oecologia 19: 345-357.

Mangel, M. \& Tier, C. 1994: Four facts every conservation biologist should know about persistence. - Ecology 75 : 607-614.

Mitchell, S. C. 2005: How useful is the concept of habitat? A critique. - Oikos 110: 634-638.

Moran, M. D. 2003: Arguments for rejecting the sequential Bonferroni in ecological studies. - Oikos 100: 403-405.

Nielsen, S. E., Johnson, C. J., Heard, D. C. \& Boyce, M. S.
2005: Can models of presence-absence be used to scale abundance? Two case studies considering extremes in life history. - Ecography 28: 197-208.

Olden, J. D. \& Jackson, D. A. 2002: A comparison of statistical approaches for modelling fish species distributions. - Freshwater Biology 47: 1976-1995

Olden, J. D., Jackson, D. A. \& Peres-Neto, P. 2002: Predictive models of fish species distributions: a note on proper validation and chance predictions. - Transactions of the American Fisheries Society 131: 329-336.

Olden, J. D., Lawler, J. J. \& Poff, N. L. 2008: Machine learning methods without tears: a primer for ecologists. The Quarterly Review in Biology 83: 171-193.

Özesmi, U., Tan, C. O. \& Özesmi, S. L. 2006b: Methodological issues in building, training, and testing artificial neural networks in ecological applications. - Ecological Modelling 195: 83-93.

Özesmi, U., Tan, C. O., Özesmi, S. L. \& Robertson, R. J. 2006a: Generalizability of artificial neural network models in ecological applications: predicting nest occurrence and breeding success of the red-winged blackbird Agelaius phoeniceus. - Ecological Modelling 195: 94-104.

Pearce, J. \& Ferrier, S. 2001: The practical value of modelling relative abundance of species for regional conservation planning: a case study. - Biological Conservation 98: $33-43$.

Perneger, T. V. 1998: What's wrong with Bonferroni adjustments. - British Medical Journal 316: 1236-1238.

Peterson, A. T. 2006: Uses and requirements of ecological niche models and related distributional models. - Biodiversity Informatics 3: 59-72.

Peterson, A. T., Papeş, M. \& Soberón, J. 2008: Rethinking receiver operating characteristic analysis applications in ecological niche modelling. - Ecological Modelling 213: 63-72.

Pulliam, H. R. 2000: On the relationship between niche and distribution. - Ecology Letters 3: 349-361.

R Development Core Team 2004: R: A language and environment for statistical computing. - $\mathrm{R}$ Foundation for Statistical Computing, Vienna, Austria, available at www.R-project.org.

Real, R., Barbosa, A. M., Rodríguez, A., García, F. J., Vargas, J. M., Palomo, J. \& Delibes, M. 2009: Conservation biogeography of ecologically interacting species: the case of the Iberian lynx and the European rabbit. - Diversity and Distributions 15: 390-400.

Recknagel, F. 2001: Applications of machine learning to ecological modelling. - Ecological Modelling 146: 303-310

Regan, H. M., Colyvan, M. \& Burgman, M. A. 2000: A proposal for fuzzy International Union for the conservation of Nature (IUCN) categories and criteria. - Biological Conservation 92: 101-108.

Ripley, B. D. 1996: Pattern recognition and neural networks. - Cambridge University Press, Cambridge.

Russell, K. R., Mabee, T. J. \& Cole, M. B. 2004: Distribution and habitat of Columbia torrent salamanders at multiple spatial scales in managed forests of northwestern Oregon. - Journal of Wildlife Management 68: 403-415.

Schadt, S., Revilla, E., Wiegand, T., Knauer, F., Kaczensky, 
P., Breitenmoser, U., Bufka, L., Červený, J., Koubek, P., Huber, T., Staniša, C. \& Trepl, L. 2002: Assessing the suitability of central European landscapes for the reintroduction of Eurasian lynx. - Journal of Applied Ecology 39: 189-203.

Scott, J. M., Heglund, P. J., Haufler, J. B., Morrison, M., Raphael, M. G., Wall, W. B. \& Samson, F. (eds.) 2002: Predicting species occurrences. Issues of accuracy and scale. - Island Press, Covelo, CA.

Segurado, P. \& Araújo, M. B. 2004: An evaluation of methods for modelling species distributions. - Journal of Biogeography 31: 1555-1568.

Shmida, A. \& Wilson, M. V. 1985: Biological determinants of species diversity. - Journal of Biogeography 12: 1-20.

Sing, T., Sander, O., Beerenwinkel, N. \& Lengauer, T. 2005: ROCR: Visualizing the performance of scoring classifiers. - R package ver. 1.0-1, available at rocr.bioinf. mpi-sb.mpg.de.

Smith, R. S., Gaston, K. J., Warren, P. H. \& Thompson K. 2006: Urban domestic gardens (VIII): environmental correlates of invertebrate abundance. - Biodiversity and Conservation 15: 2515-2545.

Soberón, J. 2007: Grinnellian and Eltonian niches and geographic distribution of species. - Ecology Letters 10:
1115-1123.

Soberón, J. \& Peterson, A. T. 2004: Biodiversity informatics: managing and applying primary biodiversity data. - Philosophical Transactions of the Royal Society of London B 359: 689-698.

Soberón, J. \& Peterson, A. T. 2005: Interpretation of models of fundamental ecological niches and species' distributional areas. - Biodiversity Informatics 2: 1-10.

Stewart-Oaten, A., Murdoch, W. W. \& Walde, S. J. 1995: Estimation of temporal variability in populations. American Naturalist 146: 519-535.

Swets, J. A. 1988: Measuring the accuracy of diagnostic systems. - Science 240: 1285-1293.

Tyre, A. J., Possingham, H. P. \& Lindenmayer, D. B. 2001: Inferring process from pattern: can territory occupancy provide information about life history parameters? Ecological Applications 11: 1722-1737.

Van Horne, B. 1983: Density as a misleading indicator of habitat quality. - Journal of Wildlife Management 47: 893-901.

Venables, W. N. \& Ripley, B. D. 2002: Modern applied statistics with S. - Springer, New York.

Wise, D. H. 1993: Spiders in ecological webs. - Cambridge University Press, New York.

Appendix. Colonization status (END = Azorean endemic; $M A C=$ Macaronesian endemic; $\mathrm{N}=$ native; $\mathrm{I}=$ introduced; $-=$ no information available; following Borges et al. 2005b) and mean abundance (and range) of each species.

\begin{tabular}{|c|c|c|c|c|c|}
\hline Species & $\begin{array}{c}\text { Colonization } \\
\text { status }\end{array}$ & $\begin{array}{c}\text { Mean } \\
\text { abundance } \\
\text { (range) }\end{array}$ & Species & $\begin{array}{l}\text { Colonization } \\
\text { status }\end{array}$ & $\begin{array}{c}\text { Mean } \\
\text { abundance } \\
\text { (range) }\end{array}$ \\
\hline Araneae & & & Cordalia obscura & 1 & $4.06(1-24)$ \\
\hline Agyneta decora & I & $3.21(1-9)$ & Epuraea biguttata & 1 & $4.00(1-11)$ \\
\hline Dysdera crocata & 1 & $4.14(1-21)$ & Heteroderes azoricus & END & $74.50(3-204)$ \\
\hline Eperigone bryantae & I & $4.06(1-19)$ & Hirticomus quadriguttatus & $\mathrm{N}$ & $94.64(3-589)$ \\
\hline Eperigone fradeorum & I & $5.00(1-33)$ & Ocypus (Pseudocypus) aethiops & $\mathrm{N}$ & $10.10(1-60)$ \\
\hline Erigone atra & I & $9.29(1-41)$ & Pseudoophonus rufipes & 1 & $5.73(1-18)$ \\
\hline Erigone autumnalis & I & $23.32(1-69)$ & Pterostichus (Argutor) vernalis & I & $14.77(1-81)$ \\
\hline Erigone dentipalpis & 1 & $47.23(1-121)$ & Rugilus orbiculatus orbiculatus & $\mathrm{N}$ & $6.41(1-27)$ \\
\hline Ero furcata & I & $1.74(1-9)$ & Sericoderus lateralis & 1 & $2.70(1-7)$ \\
\hline Lepthyphantes acoreensis & END & $5.42(1-18)$ & Sitona discoideus & 1 & $5.00(1-14)$ \\
\hline Meioneta fuscipalpis & I & $18.83(1-68)$ & Sphenophorus abbreviatus & 1 & $2.00(1-6)$ \\
\hline Oedothorax fuscus & I & $442.07(10-1081)$ & Stelidota geminata & I & $9.33(1-58)$ \\
\hline Ostearius melanopygius & 1 & $6.00(1-32)$ & Typhaea stercorea & 1 & $18.85(1-120)$ \\
\hline Pachygnatha degeeri & I & $7.93(1-32)$ & Xantholinus longiventris & I & $1.93(1-6)$ \\
\hline Palliduphantes schmitzi & MAC & $2.65(1-16)$ & Dermaptera & & \\
\hline Pardosa acoreensis & END & $22.22(1-188)$ & Forficula auricularia & - & $13.29(1-42)$ \\
\hline Porrhomma borgesi & END & $1.54(1-3)$ & Diplopoda & & \\
\hline Prinerigone vagans & 1 & $8.37(1-37)$ & Cylindroiulus propinquus & 1 & $3.60(1-10)$ \\
\hline Rugathodes acoreensis & END & $4.94(1-17)$ & Polydesmus coriaceus & 1 & $4.83(1-26)$ \\
\hline Blattaria & & & Hemiptera & & \\
\hline Zetha vestita & - & $1.47(1-3)$ & Anoscopus albifrons & - & $6.36(1-40)$ \\
\hline Chilopoda & & & Aphrodes hamiltoni & END & $5.43(1-19)$ \\
\hline Geophilus truncorum & $\mathrm{N}$ & $1.11(1-2)$ & Nabis pseudoferus ibericus & $\mathrm{N}$ & $4.62(1-16)$ \\
\hline Coleoptera & & & Pseudoescropiones & & \\
\hline Aleochara bipustulata & 1 & $3.00(1-15)$ & Chthonius ischnocheles & - & $5.74(1-14)$ \\
\hline Amischa analis & I & $4.80(1-15)$ & Chthonius tetrachelatus & - & $2.73(1-8)$ \\
\hline Anisodactylus binotatus & I & $3.00(1-9)$ & Opiliones & & \\
\hline Calosoma olivieri & $\mathrm{N}$ & $2.33(1-8)$ & Homalenotus coriaceus & - & $22.00(1-147)$ \\
\hline Chaetocnema hortensis & I & $12.00(1-71)$ & & & \\
\hline
\end{tabular}

